\title{
In Pursuit of State Aid
}

\author{
Nancy F. Bates
}

Lobbying for state aid has never been, to paraphrase Euclid, a royal road. In truth, history shows the way to be rocky, steep, and filled with potholes, detours, and dead ends. It took twelve years to sell the idea of state aid to the General Assembly and in the intervening forty-four years, increases have often been small and sporadic. For example, from 1941 to 1983 , it was feast or famine with biennial increased fluctuating from $\$ 665$ in $1959-61$ to $\$ 1,316,353$ in $1973-75 .^{1}$

This hit and miss approach to funding probably can be attributed largely to the lack of an organized, grassroots lobby to speak out for a better level of support and, to the fact, according to a study by Oliver Garceau, that "librarians were not facing the realism of the political structure of which they, inevitably, were a part." He also found that "by and large, librarians did not consider themselves as employees of government or as members of a public bureaucracy. Public administration was-and is-a political process, and librarians needed to understand and appreciate clearly the political world of the public library."

\section{Political Astuteness Grows}

Fortunately, in the last six or eight years public librarians have become more politically astute realizing that elected officials, whether local or state, listen to the people who put them in office. We have begun to look at the large block of voters who patronize our libraries and ask these citizens for assistance in petitioning county commissioners and legislators. The past four years have proven that public libraries are not without friends. In some cases it has been simply a matter of making supporters aware of the library's needs and problems.

Librarians have also become more cognizant of the old adage, "there is strength in numbers." In 1979 the North Carolina Public Library Directors Association was formed having as one of its aims the improvement of communications with local and state governmental officials. Along with the

Nancy F. Bates is Director of the Davidson County Public Library.
Governmental Relations Committee of the Public Library Section of NCLA, the association has been a catalyst in setting and carrying out legislative goals. In 1980 concerned citizens and librarians joined together in organizing the Friends of North Carolina Public Libraries. One of this group's objectives was to foster closer relations between libraries and the state's citizenry thus increasing the public's awareness of library services.

To say that the efforts of these groups were successful from the beginning would be misleading, to say the least. For the first two years, there remained considerable lack of unity and purpose as different segments pursued their own agenda with individual legislators. This lack of organization created dissension and turmoil prompting some legislators to advise, "librarians get your act together."

\section{Groups Join Forces}

Taking this message to heart, the groups joined forces with the common goal of securing a six million dollar increase in state aid for the 1983-85 biennium. The strategy consisted of personal contacts with key legislators and intense phone and letter campaigns by directors, library staff, trustees, friends, and patrons.

With limited financial resources available for lobbying, the Governmental Relations Committees of PLS and PLDA were forced to rely on their ingenuity to capture the attention of the General Assembly. The decision was made to provide each legislator with a brief informational brochure as well as a small, inexpensive but very clever favor. In 1982, the theme was carried out with a pocket of peanuts using the caption "Public libraries operate for peanuts. Here's a pocketful for you!" At General Assembly Library Day in March, 1983, each legislator was given a yellow rose and ribbon which said, "Pin a rose on you for supporting public libraries." In July when the six million dollars was appropriated for the biennium, small baskets of peaches were presented to key legislators who had made possible the passage of the measure. The tag line read, "You're a real peach! Thanks for supporting public libraries." 
Flushed with the success of the previous biennium and realizing we were on to a good thing, the lobbying effort gathered new strength. Committee members racked their brains for an innovative, showstopping way to thank members of the General Assembly for the 1983-85 appropriation and for strategy to secure another six million dollars for the 1985-87 biennium. Seizing upon a patriotic topic, library directors visited the General Assembly on February 19, 1985, giving every legislator an informational brochure along with a small apple pie topped with a miniature American flag and the slogan "Public libraries are as American as apple pie. Thanks for giving us our slice!"

A month or so later, Senator Harold Hardison and Representative Billy Watkins introduced twin bills for the sum of $\$ 3,000,000$ for FY $1985-86$ and $\$ 3,150,000$ for FY $1986-87$ to increase state aid to public libraries. Twenty senators and twentyeight representatives signed the measures in a show of bipartisan support. John Jones, Nancy Massey, and Arial Stephens are to be commended for their persuasive efforts with Senator Hardison and Representative Watkins respectively. On July 18,1985 , Senate Bill 182 was ratified by the General Assembly. Contained in this appropriation measure for the $1985-87$ biennium was $\$ 6$ million dollars for state aid to public libraries.

\section{Benefits}

Perhaps the greatest benefit to be derived from the lobbying effort, in addition to the increased funding, has been establishing visibility, rapport, and credibility with the General Assembly. Legislators now know what services libraries perform, how many citizens use libraries, and how libraries contribute to their communities. They are very much aware that state aid reaches every county and has the potential of touching the lives of every citizen in North Carolina.

Librarians also have gained much from this experience as, we hope, we have lost some of our political naivete. Alice Ihrig has said, "Perhaps the job description for any librarian should read, in part ... has knowledge of the political process, and is willing and eager to be involved as an individual in making the process work for the good of the people served by this library."'3

Many people deserve credit for the twelve million dollar (125\%) increase in state aid over the past four years. As Chairman of the PLS Governmental Relations Committee and President of NCPLDA, I want to express my sincerest appreciation to librarians, trustees, friends, and users for their time and effort. Without the continuous flow of letters and phone calls, the endeavor would not have succeeded. There are those, however, as there are in any venture, who went above and beyond the call of duty. These individuals are best described in the words of James Bryant Conant: "Each honest calling, each walk of life, has its own elite, its own aristocracy based on excellence of performance."

\section{Special Thanks}

In alphabetical order, our aristocracy includes Members of the General Assembly: Former Representative Allen Adams, Representative Bobby Etheridge, Representative Joe Mavretic, Senator Harold Hardison, Senator Aaron Plyler, Senator Tony Rand, and Representative Billy Watkins; Trustees: Jake Killian and Perry White. Librarians: Louise Boone, Bill Bridgman, Martha Davis, Mary Jo Godwin, Henry Hall, Barbara Johnson, John Jones, Nancy Massey, Wayne Modlin, Doug Perry, Margaret Randall, Arial Stephens, Judith Sutton, and Jerry Thrasher. A special note of thanks to David McKay and the State Library staff for their support and hard work especially on General Assembly Library Day.

\section{References}

1. Thornton W. Mitchell, The State Library and Library Development in North Carolina (Raleigh: North Carolina Department of Cultural Resources, Division of State Library, 1983):141-142.

2. Oliver Garceau, A Report of the Public Library Inquiry: The Public Library in the Political Process (New York: Columbia University Press, 1949):111, 238-239.

3. Alice Thrig, "Librarians and the political process," in As Much to Learn as to Teach, edited by Joel M. Lee and Beth A. Hamilton (Linnet Books, 1979):93.

4. John Bartlett, Familiar Quotations (Boston: Little, Brown and Company, 1968):1026.

\section{Copies of articles from this publication are now available from the UMI Article Clearinghouse. TUMIJ]Article
Clearinghouse}

Mail to: University Microfilms International 300 North Zeeb Road. Box 91 Ann Arbor. Ml 48106 